\title{
Glass half empty? Lessons learned about gastroparesis
}

\section{[version 1; peer review: 3 approved]}

\author{
Patrick McKenzie ${ }^{1}$, Klaus Bielefeldt 1,2 \\ ${ }^{1}$ Division of Gastroenterology, University of Utah, UT, USA \\ ${ }^{2}$ Gastroenterology Section, George E. Wahlen Department of Veterans Affairs Medical Center, 500 Foothill Drive, Salt Lake City, UT \\ 84103, USA
}

V1 First published: 08 May 2018, 7(F1000 Faculty Rev):560

https://doi.org/10.12688/f1000research.14043.1

Latest published: 08 May 2018, 7(F1000 Faculty Rev):560

https://doi.org/10.12688/f1000research.14043.1

\section{Open Peer Review}

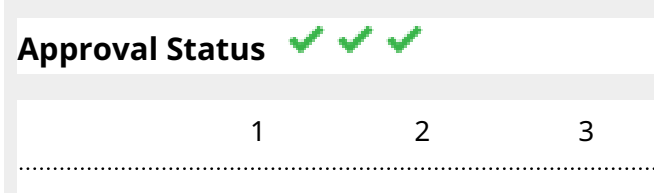

version 1

08 May 2018

Faculty Reviews are review articles written by the prestigious Members of Faculty Opinions. The articles are commissioned and peer reviewed before publication to ensure that the final, published version is comprehensive and accessible. The reviewers who approved the final version are listed with their names and affiliations.

1. Nuggehally R. Srinivas, Zydus Research Center, Ahmedabad, Gujarat, India

2. Paul A.M. Smeets, Wageningen University \& Research, Wageningen, The Netherlands

3. Tamas Ordog, Mayo Clinic, Rochester, Minnesota, USA

Any comments on the article can be found at the end of the article.

\section{Keywords}

Gastroparesis; macrophages; gastric emptying 
Corresponding author: Klaus Bielefeldt (klaus.bielefeldt@va.gov)

Author roles: McKenzie P: Conceptualization, Writing - Original Draft Preparation; Bielefeldt K: Conceptualization, Supervision, Writing - Review \& Editing

Competing interests: No competing interests were disclosed.

Grant information: The author(s) declared that no grants were involved in supporting this work.

Copyright: $\odot 2018$ McKenzie P and Bielefeldt K. This is an open access article distributed under the terms of the Creative Commons Attribution License, which permits unrestricted use, distribution, and reproduction in any medium, provided the original work is properly cited. Data associated with the article are available under the terms of the Creative Commons Zero "No rights reserved" data waiver (CC0 1.0 Public domain dedication).

How to cite this article: McKenzie $P$ and Bielefeldt K. Glass half empty? Lessons learned about gastroparesis [version 1; peer review: 3 approved] F1000Research 2018, 7(F1000 Faculty Rev):560 https://doi.org/10.12688/f1000research.14043.1

First published: 08 May 2018, 7(F1000 Faculty Rev):560 https://doi.org/10.12688/f1000research.14043.1 
Eating not only ensures survival but also is part of the social fabric. Meals often function as times for social interaction, as symbols of hospitality, or as a central aspect of celebrations. Thus, illnesses that limit the ability to partake in this important daily activity have a disproportionately high impact on quality of life ${ }^{1}$. About 60 years ago, Kassander coined the term gastroparesis, describing it as a consequence of vagal neuropathy in diabetics with secondary complications ${ }^{2}$. We have since gained significant insight into the normal and abnormal function of the stomach, developed and standardized a disease definition and diagnostic approaches, and employed a wide range of treatments from diet to medications and endoscopic and surgical therapies. Current consensus statements highlight the importance of delayed gastric emptying, typically documented by measuring the exit of a solid test meal from the stomach, and the chronic presence of dyspeptic symptoms, such as nausea, vomiting, post-prandial fullness, early satiety, anorexia, and abdominal discomfort $^{3}$. Yet, given the repeatedly disappointing results of interventions that target disease-defining mechanisms, such as motilin or ghrelin agonists ${ }^{4-8}$, are we still facing a "conundrum", as Longstreth lamented more than a decade ago? ? Since then, several investigations have shifted our understanding of the start of gastroparesis and this has affected clinical practice.

\section{Is it time to de-emphasize emptying time as endophenotype?}

As mentioned above, gastroparesis is defined by a delay in gastric emptying, which differentiates it from functional dyspepsia or chronic unexplained nausea. The impaired emptying has traditionally been the target of treatments and often functioned as a key endpoint in clinical trials ${ }^{5,6}$. Yet gastric emptying does not consistently correlate with symptom severity, whether assessed with a labeled meal or a large undigestible particle, such as the wireless motility capsule ${ }^{10,11}$. This limited correlation could be due in part to a focus on the wrong endpoint, such as half-emptying time, rather than the fraction of a test meal retained after a predefined time ${ }^{12}$. The relationship between gastric emptying and symptoms improved when acute, meal-induced rather than recall-based severity ratings covering a longer period were used ${ }^{13-15}$. These chronic complaints and acute, experimentally evoked symptoms are conceptually related; however, trial endpoints and drug approval criteria target the chronic symptoms as clinically validated and relevant endpoints. Interestingly, a recent cohort study described similar symptoms and symptom severity between type 1 and type 2 diabetics, even though gastric emptying was slower in type 1 diabetes, thus similarly pointing away from this variable as the sole or even primary determinant of disease severity ${ }^{16}$. Conversely, the perceived benefit of treatments does not correlate with changes in gastric emptying ${ }^{17}$. Lastly, gastric emptying does not reliably do what it is supposed to do as a biomarker, namely differentiate patients with overlapping symptoms but different disorders. Close to $90 \%$ of patients with gastroparesis meet the consensus definition of functional dyspepsia and about $20 \%$ of patients with functional dyspepsia have impaired emptying independent of their symptom pattern ${ }^{10,18}$. Similarly, a recent study characterized patients with chronic unexplained nausea, which phenotypically overlapped with gastroparesis except for the normal results of gastric-emptying studies ${ }^{19}$. The overlap goes beyond symptoms and changes in emptying as detailed physiological studies showed coexisting changes in accommodation and sensory mechanisms in gastroparesis ${ }^{20}$. If we look at mechanistic studies, we still see more parallels than differences as patients with otherwise-unexplained nausea and vomiting share some of the microscopic abnormalities on full-thickness gastric biopsies that otherwise have been associated with gastroparesis ${ }^{21}$. Looking for alternative explanations related to gastric motor function, a small study suggested a potential correlation between symptoms and integrated motor activity ${ }^{22}$, a finding that subsequent investigations did not confirm in a substantially larger cohort with 209 participants $^{11}$. Thus, we may deal with a spectrum of abnormalities that overlap in symptoms, test results, and underlying pathophysiology. Instead of making gastric emptying a key criterion for diagnosis and treatment, we may reconceptualize dyspeptic syndromes as a potential consequence of several coexisting mechanisms that contribute to a problem. Delayed emptying can clearly be one of these changes and may contribute to symptoms or symptom severity, especially the severity of nausea and vomiting ${ }^{18}$ or post-prandial symptom exacerbations ${ }^{13-15}$. Some recent data also point to the potential prognostic value of gastric-emptying data with apparently counterintuitive results, as slower emptying at baseline was associated with a better prognosis after close to one year of follow-up ${ }^{23}$.

\section{Will novel concepts bring novel treatments?}

Animal models and human data have identified a network of macrophages in the muscular layer of the stomach, which may link the immune system to changes in gastric motor function. Activation of M1 macrophages triggers the release of tumor necrosis factor alpha, which, in turn, leads to a decrease in interstitial cells of Cajal (ICCs), the electrical pacemaker cells of the gut $^{24}$. Conversely, interleukin-10 activates M2 macrophages, which protect the ICC population ${ }^{25,26}$. With animal models showing up- or downregulation of ICCs through such mechanisms and associated changes in gastric emptying ${ }^{7}$, do we need to look at this motility disorder as a problem at the interface between the immune system and neuromuscular transmission? Bharucha and colleagues recently explored this question by trying to induce heme oxygenase-1, which is expressed in M2 macrophages and plays an important anti-inflammatory role $^{8}$. Their pilot data show a potent induction of the enzyme but no influence on symptoms or emptying ${ }^{28}$. Even if macrophages or specific enzymes have not yet found their way into successful treatment strategies, these findings illustrate how preclinical data are translated into novel treatment strategies. In addition, the underlying preclinical data may function like a ray of hope as they suggest that cellular abnormalities linked to the development of gastroparesis are potentially reversible.

One conceptual model envisions impaired opening of the pyloric channel as a cause for gastric retention, providing a rationale for treatments targeting this muscle. After two negative trials of botulinum toxin injection into the pylorus ${ }^{29,30}$, the potential role of pyloric dysfunction in gastroparesis has surfaced again in two forms. On the diagnostic side, the EndoFLIP (endolumenal 
functional lumen imaging probe) device allows detailed assessments of the pylorus's active and passive mechanical properties, which seem to be altered in gastroparesis and appear to correlate with symptoms and emptying ${ }^{31,32}$. If this test is confirmed, we need to examine whether it enables us to identify a subgroup that could indeed benefit from interventions targeting this muscle structure. On the therapeutic side, per-oral endoscopic myotomy not only is feasible but also comes with impressive preliminary findings in early open-label trials ${ }^{33}$. In light of the similar early enthusiasm with botulinum toxin therapy, followed by disappointing results in randomized controlled studies ${ }^{29,30,34-37}$, it is essential to integrate more detailed functional assessments of this muscle (for example, by using the EndoFLIP) and to assess the true impact of this intervention with controlled trials.

Several other observations about treatment options and impact have emerged during the last decade. First, a consortium of tertiary referral centers completed longitudinal studies that tracked symptoms and findings in patients who received treatment at the various sites for gastroparesis. Though not standardized and thus limiting our ability to assess specific treatment approaches, management was largely driven by the very experts who set the tone in discussions about the diagnosis and treatment of this illness. The data seem to be disappointing as even in expert hands, symptoms largely remain stable with less than one third of the patients improving during follow-up ${ }^{16,23}$. As already indicated, the observational design of this cohort study does not allow conclusions about specific steps. Yet it is important to contrast this message with the results of randomized controlled trials completed recently. We compiled data from double-blinded placebo-controlled trials published within the last decade and examined response rates for dichotomized endpoints (Figure 1) or changes in severity ratings for continuous data (Figure 2). Virtually all showed only marginal or even no differences compared with placebo. However, pla-

\section{Gastroenterology 154:65 \\ JAMA 310:2640}

Neurogastroenterology 21: 632

Neurogastroenterology 25:e140

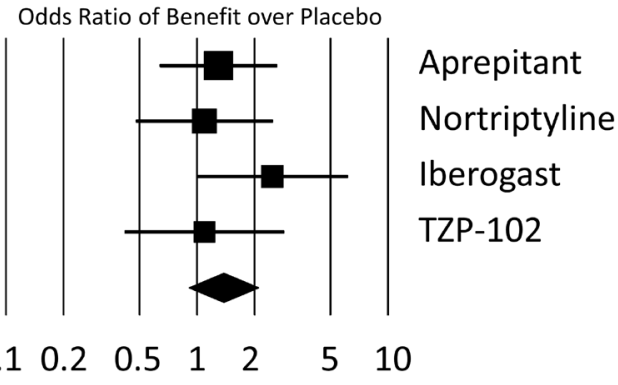

Figure 1. Summary of randomized controlled trials in gastroparesis with dichotomizing endpoints. Trials published within the last decade and providing response rates were assessed to determine the odds of active therapy being superior to placebo. All but the ghrelin agonist TZP-102 used symptom scores; TZP-102 compared gastric-emptying rates which were dichotomized based on half-emptying times of less or more than 150 minutes. Only the herbal preparation Iberogast was superior to placebo when the primary endpoint was analyzed. Studies are labeled on the basis of the publishing journal with volume and first page. JAMA, Journal of the American Medical Association; Neurogastroenterology, Neurogastroenterology \& Motility.

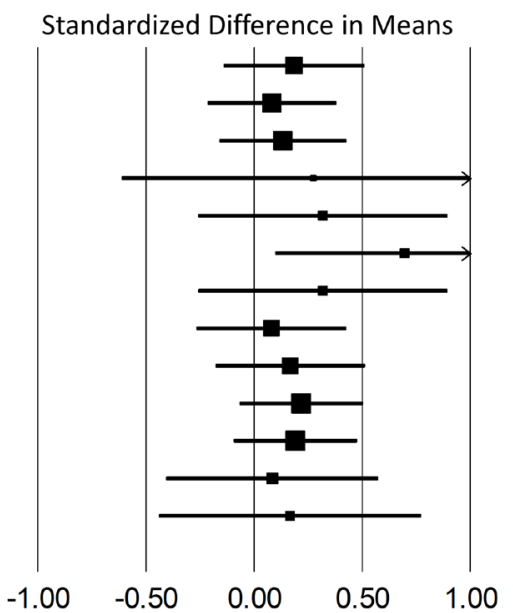

Figure 2. Differences in means between placebo and active therapy as shown in randomized controlled trials. Placebo-controlled trials published within the last decade were analyzed to depict differences in symptom scores between active interventions and placebo. All data are based on normalized mean changes in symptom scores. As the primary outcome variable for studies on gastric electrical stimulation (Enterra) was given only as median, we chose an aggregate score based on symptom frequency. CGH, Clinical Gastroenterology and Hepatology; Neurogastroenterology, Neurogastroenterology \& Motility. 
cebo responses were very high across the board, and vomiting frequency dropped by as much as $70 \%$, to cite just one example ${ }^{38}$. These results are difficult to reconcile with the largely stable symptoms reported by the consortium. In regard to one specific modality, gastric electrical stimulation, the benefit reported in retrospective case series and during the open-label trials, but not the blinded phase of controlled trials ${ }^{39-41}$, did not seem to translate into tangible changes for type 1 diabetics who often underwent device implantation as part of their management through members of the consortium ${ }^{16}$. Most drug trials focused on ghrelin agonists, and short- but not long-term studies of one agent showed benefit over placebo ${ }^{7,8,42,43}$. A phase II trial of relamorelin, another ghrelin agonist, did not demonstrate improvement in vomiting as the primary endpoint when compared with placebo, but the active intervention was superior in an analysis of some secondary endpoints ${ }^{38}$. After prior failures of motilin agonists ${ }^{4-6}$, another agent surfaced, again with promising results after a single dose in diabetics with gastroparesis ${ }^{44}$. More appropriate long-term studies will be needed to see whether the most recent introduction is indeed different from the previously tested agents with a similar mechanism. For now, the most convincing standard therapy for gastroparesis is dietary intervention ${ }^{45}$. Positive prognostic data, such as onset after an infectious prodrome, male gender, or antidepressant use, as well as negative prognostic factors, most notably opioid use and pain predominance ${ }^{23}$, may enable providers to risk-stratify and tailor treatment approach or intensity. For providers outside of tertiary referral centers, the high placebo response rates and comparable effects with approaches based on very different mechanisms of action have important implications. If numbers needed to treat do not differ dramatically between therapies, the number needed to harm (that is, the side effect profile) becomes more important. While the effects of antiemetics and other agents commonly used in gastroparesis have been less systematically studied, the controversies surrounding metoclopramide clearly highlight the relevance of this criterion in gastroparesis $^{46-48}$.

\section{Where to go from here}

With at least some of the novel treatments not meeting expectations, gastroparesis remains a difficult-to-treat disorder. However, there have been clear advances in our understanding of this and perhaps some of the other closely related diseases. In our short review, we have tried to point to potential areas for future studies. One key question, is whether we should see gastroparesis as a distinct disorder or whether it belongs in the spectrum of syndromes labeled as functional dyspepsia, as has been suggested ${ }^{49}$. Impaired motility clearly contributes to the pathophysiology of these common problems but includes more than just a delay in emptying. Thus, we need to assess whether other non-invasive tests, such as magnetic resonance imaging or single-photon emission tomography ${ }^{50,51}$, can provide a more comprehensive assessment of gastric motor function from accommodation to emptying and whether more detailed information allows more targeted and more effective therapy. If indeed emptying poorly correlates with symptoms and treatment effects, what can we offer beyond dietary advice? Recent studies give us some sense of direction, as anxiety and depression are associated with symptom severity ${ }^{10}$ and as antidepressant use functioned as a positive outcome predictor ${ }^{23}$. These results correspond to detailed mechanistic studies in functional dyspepsia that highlight the importance of affect ${ }^{52,53}$. Yet we still have to resolve some apparent contradictions, as well-designed trials led to inconsistent results with tricyclics not being superior to placebo in gastroparesis, while there was a benefit in a large cohort of patients with functional dyspepsia which included persons with impaired gastric emptying ${ }^{54,55}$. Going back to our call for a better and more comprehensive phenotypic characterization of patients, we may be able to identify subgroups with markers other than gastric emptying alone that may allow more targeted and more successful therapy. Concerns about metoclopramide led to a decreasing use of prokinetics with an apparent increase in antiemetics. Given the importance of nausea and vomiting as hallmark symptoms of gastroparesis, this development seems intuitively reasonable. However, the marginal benefit seen with aprepitant ${ }^{56}$ demonstrates the need for evidence rather than intuition. Most of our insight into the efficacy of antiemetics comes from the treatment of chemotherapyinduced nausea, which is typically an acute and only transient problem. Although the clinical manifestation may look identical, the underlying mechanisms will almost certainly differ, forcing us to better define the true benefit of these agents in gastroparesis. Perhaps most importantly, we need to develop approaches that will enable us to provide better prognostic information and treatment for patients where they are most commonly seen, outside the tertiary referral centers.

\section{Competing interests}

The authors declare that they have no competing interests.

\section{Grant information}

The author(s) declared that no grants were involved in supporting this work.
1. Bielefeldt K, Raza N, Zickmund SL: Different faces of gastroparesis. World J Gastroenterol. 2009; 15(48): 6052-60. PubMed Abstract | Publisher Full Text | Free Full Text

2. Kassander $P$ : Asymptomatic gastric retention in diabetics (gastroparesis diabeticorum). Ann Intern Med. 1958; 48(4): 797-812. PubMed Abstract | Publisher Full Text

3. Camilleri M, Parkman HP, Shafi MA, et al.: Clinical guideline: management of gastroparesis. Am J Gastroenterol. 2013; 108(1): 18-37; quiz 38. PubMed Abstract | Publisher Full Text | Free Full Text

4. Talley NJ, Verlinden M, Geenen DJ, et al.: Effects of a motilin receptor agonist (ABT-229) on upper gastrointestinal symptoms in type 1 diabetes mellitus: a randomised, double blind, placebo controlled trial. Gut. 2001; 49(3): 395-401. PubMed Abstract | Publisher Full Text | Free Full Text

5. McCallum RW, Cynshi O, Investigative Team: Clinical trial: effect of mitemcinal 
(a motilin agonist) on gastric emptying in patients with gastroparesis - a randomized, multicentre, placebo-controlled study. Aliment Pharmacol Ther. 2007; 26(8): 1121-30.

PubMed Abstract | Publisher Full Text

6. Russo A, Stevens JE, Giles N, et al.: Effect of the motilin agonist KC 11458 on gastric emptying in diabetic gastroparesis. Aliment Pharmacol Ther. 2004; 20(3): 333-8.

PubMed Abstract | Publisher Full Text

7. $\quad \mathrm{F}$ Ejskjaer N, Wo JM, Esfandyari T, et al:: A phase 2a, randomized, doubleblind 28-day study of TZP-102 a ghrelin receptor agonist for diabetic gastroparesis. Neurogastroenterol Motil. 2013; 25(2): e140-50. PubMed Abstract | Publisher Full Text | F1000 Recommendation

8. $\mathrm{F}$ McCallum RW, Lembo A, Esfandyari T, et al.: Phase 2b, randomized, doubleblind 12-week studies of TZP-102, a ghrelin receptor agonist for diabetic gastroparesis. Neurogastroenterol Motil. 2013; 25(11): e705-17. PubMed Abstract | Publisher Full Text | F1000 Recommendation

9. Longstreth GF: Functional dyspepsia--managing the conundrum. N Engl J Med. 2006; 354(8): 791-3. PubMed Abstract | Publisher Full Text

10. F Parkman HP, Yates K, Hasler WL, et al:: Clinical features of idiopathic gastroparesis vary with sex, body mass, symptom onset, delay in gastric emptying, and gastroparesis severity. Gastroenterology. 2011; 140(1): 101-15. PubMed Abstract | Publisher Full Text | Free Full Text | F1000 Recommendation

11. $\mathrm{F}$ Hasler WL, May KP, Wilson LA, et al:: Relating gastric scintigraphy and symptoms to motility capsule transit and pressure findings in suspected gastroparesis. Neurogastroenterol Motil. 2018; 30(2): e13196. PubMed Abstract | Publisher Full Text | F1000 Recommendation

12. Ardila-Hani A, Arabyan M, Waxman A, et al:: Severity of dyspeptic symptoms correlates with delayed and early variables of gastric emptying. Dig Dis Sci. 2013; 58(2): 478-87.

PubMed Abstract | Publisher Full Text

13. Samsom M, Vermeijden JR, Smout AJ, et al.: Prevalence of delayed gastric emptying in diabetic patients and relationship to dyspeptic symptoms: a prospective study in unselected diabetic patients. Diabetes Care. 2003; 26(11) 3116-22.

PubMed Abstract | Publisher Full Text

14. Olausson EA, Brock C, Drewes AM, et al.: Measurement of gastric emptying by radiopaque markers in patients with diabetes: correlation with scintigraphy and upper gastrointestinal symptoms. Neurogastroenterol Motil. 2013; 25(3): e224-32.

PubMed Abstract | Publisher Full Text

15. Khayyam U, Sachdeva P, Gomez J, et al:: Assessment of symptoms during gastric emptying scintigraphy to correlate symptoms to delayed gastric emptying. Neurogastroenterol Motil. 2010; 22(5): 539-45. PubMed Abstract | Publisher Full Text | Free Full Text

16. F Koch KL, Hasler WL, Yates KP, et al:: Baseline features and differences in 48 week clinical outcomes in patients with gastroparesis and type 1 vs type 2 diabetes. Neurogastroenterol Motil. 2016; 28(7): 1001-15.

PubMed Abstract | Publisher Full Text | Free Full Text | F1000 Recommendation

17. Janssen $P$, Harris MS, Jones $M$, et al.: The relation between symptom improvement and gastric emptying in the treatment of diabetic and idiopathic gastroparesis. Am J Gastroenterol. 2013; 108(9): 1382-91. PubMed Abstract | Publisher Full Text

18. F Vanheel H, Carbone F, Valvekens L, et al:: Pathophysiological Abnormalities in Functional Dyspepsia Subgroups According to the Rome III Criteria. Am J Gastroenterol. 2017; 112(1): 132-40. PubMed Abstract | Publisher Full Text | F1000 Recommendation

19. F Pasricha PJ, Colvin R, Yates K, et al:: Characteristics of patients with chronic unexplained nausea and vomiting and normal gastric emptying. Clin Gastroenterol Hepatol. 2011; 9(7): 567-76.e1-4.

PubMed Abstract | Publisher Full Text | Free Full Text | F1000 Recommendation

20. Kumar A, Attaluri A, Hashmi S, et al.: Visceral hypersensitivity and impaired accommodation in refractory diabetic gastroparesis. Neurogastroenterol Motil. 2008; 20(6): 635-42.

PubMed Abstract | Publisher Full Text

21. F Angeli TR, Cheng LK, Du P, et al:: Loss of Interstitial Cells of Cajal and Patterns of Gastric Dysrhythmia in Patients With Chronic Unexplained Nausea and Vomiting. Gastroenterology. 2015; 149(1): 56-66.e5. PubMed Abstract | Publisher Full Text | Free Full Text | F1000 Recommendation

22. F Barshop K, Staller K, Semler J, et al.: Duodenal rather than antral motility contractile parameters correlate with symptom severity in gastroparesis patients. Neurogastroenterol Motil. 2015; 27(3): 339-46. PubMed Abstract | Publisher Full Text | Free Full Text | F1000 Recommendation

23. Pasricha PJ, Yates KP, Nguyen L, et al: Outcomes and Factors Associated With Reduced Symptoms in Patients With Gastroparesis. Gastroenterology. 2015: 149(7): 1762-1774.e4.

PubMed Abstract | Publisher Full Text | Free Full Text

24. F Eisenman ST, Gibbons SJ, Verhulst PJ, et al:: Tumor necrosis factor alpha derived from classically activated "M1" macrophages reduces interstitial cel of Cajal numbers. Neurogastroenterol Motil. 2017; 29(4): e12984

PubMed Abstract | Publisher Full Text | Free Full Text | F1000 Recommendation

25. F Choi KM, Gibbons SJ, Sha L, et al.: Interleukin 10 Restores Gastric Emptying, Electrical Activity, and Interstitial Cells of Cajal Networks in Diabetic Mice. Cell Mol Gastroenterol Hepatol. 2016; 2(4): 454-67.

PubMed Abstract | Publisher Full Text | Free Full Text | F1000 Recommendation

26. Naito $Y$, Takagi $T$, Higashimura $Y$ : Heme oxygenase-1 and anti-inflammatory M2 macrophages. Arch Biochem Biophys. 2014; 564: 83-8.

PubMed Abstract | Publisher Full Text

27. $\mathrm{F}$ Hayashi $\mathrm{Y}$, Toyomasu $\mathrm{Y}$, Saravanaperumal SA, et al:: Hyperglycemia ncreases Interstitial Cells of Cajal via MAPK1 and MAPK3 Signaling to ETV1 and KIT, Leading to Rapid Gastric Emptying. Gastroenterology. 2017; 153(2): 521-535.e20.

PubMed Abstract | Publisher Full Text | Free Full Text | F1000 Recommendation

28. F Bharucha AE, Daley SL, Low PA, et al.: Effects of hemin on heme oxygenase-1, gastric emptying, and symptoms in diabetic gastroparesis. Neurogastroenterol Motil. 2016; 28(11): 1731-40

PubMed Abstract | Publisher Full Text | Free Full Text | F1000 Recommendation

9. Friedenberg FK, Palit A, Parkman HP, et al:: Botulinum toxin A for the treatment of delayed gastric emptying. Am J Gastroenterol. 2008; 103(2): 416-23. PubMed Abstract | Publisher Full Text

30. $\mathrm{F}$ Arts J, Holvoet L, Caenepeel $\mathrm{P}$, et al:: Clinical trial: a randomized-controlled crossover study of intrapyloric injection of botulinum toxin in gastroparesis. Aliment Pharmacol Ther. 2007; 26(9): 1251-8.

PubMed Abstract | Publisher Full Text | F1000 Recommendation

31. Malik Z, Sankineni A, Parkman HP: Assessing pyloric sphincter pathophysiology using EndoFLIP in patients with gastroparesis. Neurogastroenterol Motil. 2015 27(4): 524-31.

PubMed Abstract | Publisher Full Tex

32. F Snape WJ, Lin MS, Agarwal N, et al.: Evaluation of the pylorus with concurrent intraluminal pressure and EndoFLIP in patients with nausea and vomiting. Neurogastroenterol Motil. 2016; 28(5): 758-64.

PubMed Abstract | Publisher Full Text |F1000 Recommendation

33. F Khashab MA, Ngamruengphong S, Carr-Locke D, et al.: Gastric per-oral endoscopic myotomy for refractory gastroparesis: results from the first multicenter study on endoscopic pyloromyotomy (with video). Gastrointest Endosc. 2017; 85(1): 123-8.

PubMed Abstract | Publisher Full Text | F1000 Recommendation

34. Lacy BE, Crowell MD, Schettler-Duncan A, et al:: The treatment of diabetic gastroparesis with botulinum toxin injection of the pylorus. Diabetes Care. 2004; 27(10): 2341-7.

PubMed Abstract | Publisher Full Text

35. Bromer MQ, Friedenberg F, Miller LS, et al.: Endoscopic pyloric injection of botulinum toxin $A$ for the treatment of refractory gastroparesis. Gastrointest Endosc. 2005; 61(7): 833-9. PubMed Abstract | Publisher Full Text

36. F Arts J, van Gool S, Caenepeel P, et al.: Influence of intrapyloric botulinum toxin injection on gastric emptying and meal-related symptoms in gastroparesis patients. Aliment Pharmacol Ther. 2006; 24(4): 661-7. PubMed Abstract | Publisher Full Text | F1000 Recommendation

37. Coleski R, Anderson MA, Hasler WL: Factors associated with symptom response to pyloric injection of botulinum toxin in a large series of gastroparesis patients. Dig Dis Sci. 2009; 54(12): 2634-42.

PubMed Abstract | Publisher Full Text

38. F Camilleri M, McCallum RW, Tack J, et al:: Efficacy and Safety of Relamorelin in Diabetics With Symptoms of Gastroparesis: A Randomized, PlaceboControlled Study. Gastroenterology. 2017; 153(5): 1240-1250.e2. PubMed Abstract | Publisher Full Text | Free Full Text | F1000 Recommendation

39. McCallum RW, Snape W, Brody F, et al.: Gastric electrical stimulation with Enterra therapy improves symptoms from diabetic gastroparesis in a prospective study. Clin Gastroenterol Hepatol. 2010; 8(11): 947-54; quiz e116. PubMed Abstract | Publisher Full Text

40. McCallum RW, Lin Z, Forster J, et al:: Gastric electrical stimulation improves outcomes of patients with gastroparesis for up to 10 years. Clin Gastroenterol Hepatol. 2011; 9(4): 314-319.e1.

PubMed Abstract | Publisher Full Text

41. McCallum RW, Sarosiek I, Parkman HP, et al:: Gastric electrical stimulation with Enterra therapy improves symptoms of idiopathic gastroparesis. Neurogastroenterol Motil. 2013; 25(10): 815-e636. PubMed Abstract | Publisher Full Text | Free Full Text

42. Ejskjaer N, Vestergaard ET, Hellström PM, et al:: Ghrelin receptor agonist (TZP-101) accelerates gastric emptying in adults with diabetes and symptomatic gastroparesis. Aliment Pharmacol Ther. 2009; 29(11): 1179-87. PubMed Abstract | Publisher Full Text

43. Wo JM, Ejskjaer N, Hellström PM, et al.: Randomised clinical trial: ghrelin agonist TZP-101 relieves gastroparesis associated with severe nausea and vomiting-randomised clinical study subset data. Aliment Pharmacol Ther. 2011; 33(6): $679-88$.

PubMed Abstract | Publisher Full Text 
44. F Hellström PM, Tack J, Johnson LV, et al: The pharmacodynamics, safety and pharmacokinetics of single doses of the motilin agonist, camicinal, in type 1 diabetes mellitus with slow gastric emptying. Br J Pharmacol. 2016; 173(11): 1768-77.

PubMed Abstract | Publisher Full Text | Free Full Text | F1000 Recommendation

45. F Olausson EA, Störsrud S, Grundin H, et al:: A small particle size diet reduces upper gastrointestinal symptoms in patients with diabetic gastroparesis: a randomized controlled trial. Am J Gastroenterol. 2014; 109(3): 375-85. PubMed Abstract | Publisher Full Text | F1000 Recommendation

46. Bielefeldt K: From Harmful Treatment to Secondary Gain: Adverse Event Reporting in Dyspepsia and Gastroparesis. Dig Dis Sci. 2017; 62(11): 2999-3013. PubMed Abstract | Publisher Full Text

47. F Ehrenpreis ED, Deepak $\mathrm{P}$, Sifuentes $\mathrm{H}$, et al:: The metoclopramide black box warning for tardive dyskinesia: effect on clinical practice, adverse event reporting, and prescription drug lawsuits. Am J Gastroenterol. 2013; 108(6): $866-72$

PubMed Abstract | Publisher Full Text | F1000 Recommendation

48. Ehrenpreis ED, Roginsky G, Alexoff A, et al.: Domperidone is Commonly Prescribed With QT-Interacting Drugs: Review of a Community-based Practice and a Postmarketing Adverse Drug Event Reporting Database. J Clin Gastroenterol. 2017; 51(1): 56-62. PubMed Abstract | Publisher Full Text

49. F Enck P, Azpiroz F, Boeckxstaens G, et al:: Functional dyspepsia. Nat Rev Dis Primers. 2017; 3: 17081

PubMed Abstract | Publisher Full Text | F1000 Recommendation

50. Breen M, Camilleri M, Burton D, et al: Performance characteristics of the measurement of gastric volume using single photon emission computed tomography. Neurogastroenterol Motil. 2011; 23(4): 308-15.

PubMed Abstract | Publisher Full Text | Free Full Text

51. de Zwart IM, de Roos A: MRI for the evaluation of gastric physiology. Eur Radiol. 2010; 20(11): 2609-16.

PubMed Abstract | Publisher Full Text | Free Full Text

52. F Van Oudenhove L, Vandenberghe J, Geeraerts B, et al.: Determinants of symptoms in functional dyspepsia: gastric sensorimotor function, psychosocial factors or somatisation? Gut. 2008; 57(12): 1666-73. PubMed Abstract | Publisher Full Text | F1000 Recommendation

53. Van Oudenhove L, Vandenberghe J, Vos R, et al:: Abuse history, depression, and somatization are associated with gastric sensitivity and gastric emptying in functional dyspepsia. Psychosom Med. 2011; 73(8): 648-55. PubMed Abstract | Publisher Full Text

54. F Parkman HP, Van Natta ML, Abell TL, et al:: Effect of nortriptyline on symptoms of idiopathic gastroparesis: the NORIG randomized clinical trial. JAMA. 2013; 310(24): 2640-9.

PubMed Abstract | Publisher Full Text | Free Full Text | F1000 Recommendation

55. F Lacy BE, Saito YA, Camilleri M, et al:: Effects of Antidepressants on Gastric Function in Patients with Functional Dyspepsia. Am J Gastroenterol. 2018; 113(2): 216-24.

PubMed Abstract | Publisher Full Text | F1000 Recommendation

56. F Pasricha PJ, Yates KP, Sarosiek I, et al.: Aprepitant Has Mixed Effects on Nausea and Reduces Other Symptoms in Patients With Gastroparesis and Related Disorders. Gastroenterology. 2018; 154(1): 65-76.e11. PubMed Abstract | Publisher Full Text | Free Full Text | F1000 Recommendation 


\section{Open Peer Review}

\section{Current Peer Review Status:}

\section{Editorial Note on the Review Process}

Faculty Reviews are review articles written by the prestigious Members of Faculty Opinions. The articles are commissioned and peer reviewed before publication to ensure that the final, published version is comprehensive and accessible. The reviewers who approved the final version are listed with their names and affiliations.

\section{The reviewers who approved this article are:}

\section{Version 1}

\section{Tamas Ordog}

Department of Physiology and Biomedical Engineering, Division of Gastroenterology and Hepatology, and Center for Individualized Medicine, Mayo Clinic, Rochester, Minnesota, USA

Competing Interests: No competing interests were disclosed.

\section{Paul A.M. Smeets}

Division of Human Nutrition, Wageningen University \& Research, Wageningen, The Netherlands

Competing Interests: No competing interests were disclosed.

\section{Nuggehally R. Srinivas}

Zydus Research Center, Ahmedabad, Gujarat, India

Competing Interests: No competing interests were disclosed.

The benefits of publishing with F1000Research:

- Your article is published within days, with no editorial bias

- You can publish traditional articles, null/negative results, case reports, data notes and more

- The peer review process is transparent and collaborative

- Your article is indexed in PubMed after passing peer review

- Dedicated customer support at every stage

For pre-submission enquiries, contact research@f1000.com 